\title{
EXCHANGE
}

\section{Sunstein's New Canons: Choosing the Fictions of Statutory Interpretation}

\author{
Eben Moglen† and Richard J. Pierce, Jr. $\dagger$
}

In Interpreting Statutes in the Regulatory State, ${ }^{1}$ Cass Sunstein grapples with two of the most difficult and important questions concerning governance of the modern administrative state. First, what institution should have the dominant role in interpreting ambiguous agency-administered statutes? And second, how should the institution perform that task? Sunstein rejects the Supreme Court's answer to the first question, characterizing its assignment of a dominant interpretive role to agencies in Cheuron U.S.A., Inc. $v$ Natural Resources Defense Council" as "the fox guarding the hen house." Sunstein prefers to charge judges with the responsibility of resolving most interpretive disputes. In answer to the second question, he constructs a new canonical

$\dagger$ Associate Professor of Law, Columbia University.

†† Paul J. Kellner Professor of Law, Columbia University. Michael Herz, Henry Monaghan, Richard Revesz, and Peter Strauss provided helpful comments on an earlier version of this article.

${ }_{1}^{1}$ Cass R. Sunstein, Interpreting Statutes in the Regulatory State, 103 Harv L Rev 405 (1989).

${ }^{2} 467$ US 837 (1984). The Court allocated institutional responsibility for statutory interpretation using a two-step approach:

First, always, is the question whether Congress has directly spoken to the precise question at issue. If the intent of Congress is clear, that is the end of the matter; for the court, as well as the agency, must give effect to the unambiguously expressed intent of Congress. If, however, the court determines Congress has not directly addressed the precise question at issue, the court does not simply impose its own construction on the statute, as would be necessary in the absence of an administrative interpretation. Rather, if the statute is silent or ambiguous with respect to the specific issue, the question for the court is whether the agency's answer is based on a permissible construction of the statute.

Id at 842-43.

'Sunstein, 103 Harv L Rev at 446 (cited in note 1). 
roadmap to guide judges in performing this interpretive function. Sunstein's goal is not merely to answer two of the most perplexing questions in public law, however. His proposed interpretive roadmap is designed simultaneously to solve the public policy puzzle that most vexes students of political science, political economics, and public law: How can government close the yawning gap between the large and theoretically attainable benefits of agencyadministered statutory schemes and the modest benefits frequently combined with perverse effects that government intervention actually yields? Sunstein attributes this disappointing disparity to a series of political and regulatory pathologies identified in the social science literature. ${ }^{4}$ His proposed solutions to the problems that plague the administrative state then coincide with his proposed answers to the two public law questions he addresses: Judges ${ }^{5}$ should interpret agency-administered statutes in ways that counteract political and regulatory pathologies.

Thus, Sunstein premises his canons of statutory interpretation on modern understandings of the fallibility of the political institutions comprising the administrative state: Congress and agencies. The administrative state, according to Sunstein, often yields suboptimal results because the political institutions depart too frequently from the liberal republican understanding of individual and political freedom. If they adhered to this understanding, they would resolve all policy disputes by applying the principles of deliberation, civic virtue, equality of political actors, universalism, practical reason, and broadly guaranteed rights of participation. ${ }^{6}$ In Sunstein's vision of the administrative state, the judiciary bears the herculean responsibility of rescuing society from majoritarian and minoritarian factionalism and other pathologies that pervade the political institutions. If judges identify policy decisions that appear to be products of improper motivation or inadequate deliberation, it is their responsibility to amend those decisions in order to create the kinds of policies that would have been created by political institutions adhering consistently to liberal republican

Id at $463,466-68,476$.

- As Sunstein notes in his reply, Principles, not Fictions, 57 U Chi L Rev 1247, 1249 (1990), his canons are also aimed at the agencies; see also Sunstein, 103 Harv L Rev at 504 (cited in note 1) ("The interpretive principles suggested here are intended for the President, regulatory agencies, and Congress, as well as for the courts."). Sunstein's primary audience seems to be the judiciary, however.

- Sunstein is extending the theme he introduced in Beyond the Republican Revival, 97 Yale L J 1539, 1541 (1988). 
principles. ${ }^{7}$ Sunstein's canons guide the judges through this amendment process.

Sunstein begins his article by rejecting all prior systems of statutory interpretation because they are indeterminate, incomplete, or based on fictions. ${ }^{8}$ In Part I, we address the latter two bases for rejecting traditional interpretive regimes. We accept Sunstein's assertion that traditional systems are incomplete and premised on fictions. ${ }^{\circ}$ We argue, however, that all methods of statutory interpretation, including Sunstein's proposed canonical system, necessarily share these traits. Indeed, incompleteness is an essential feature of any system of statutory construction. A "complete" system would be intractable.

Similarly, we accept Sunstein's characterization of traditional regimes as premised on fictions, ${ }^{10}$ but not the pejorative connotation he attaches to that characterization. All interpretive systems necessarily rest upon fictions. The real legislative history of any statutory enactment is not retrievable. Even if it were, the story would be so complex and ambiguous that it would be useless to most audiences. Sunstein's failure to recognize the necessarily in-

Id at 1581-89.

- Sunstein, 103 Harv L Rev at 412-51, 503-04 (cited in note 1).

- There are, of course, numerous competing theories of statutory interpretation. Sunstein describes, and criticizes, many traditional approaches grouped in four broad categories: textualism, contextual approaches, legal process approaches, and use of extratextual norms. Sunstein, 103 Harv L Rev at $415-51$ (cited in note 1).

In this article, we attempt neither to engage in systematic evaluation and comparison of the many competing theories nor to construct our own theory of statutory interpretation. Our goal is much more modest: to convince readers that Sunstein's proposed system asks more of judges than they are capable of providing, and does so on the basis of fictions concerning legislative behavior no less fictional than those used by approaches Sunstein condemns. In other writings, one of the authors has proposed a competing system that asks less of judges by conferring greater discretion on agencies. See Richard J. Pierce, Jr., The Role of the Judiciary in Implementing an Agency Theory of Government, 64 NYU L Rev 1239 (1989); Richard J. Pierce, Jr., Chevron and its Aftermath: Judicial Review of Agency Interpretations of Statutory Provisions, 41 Vand L Rev 301 (1988); Richard J. Pierce, Jr., Political Accountability and Delegated Power: A Response to Professor Lowi, 36 Am U L Rev 391, 407-17 (1987); Richard J. Pierce, Jr., The Role of Constitutional and Political Theory in Administrative Law, 64 Tex L Rev 469 (1985).

10 Sunstein, 103 Harv L Rev at 425 (cited in note 1) (structuralism depends on the assumption that statutes are internally consistent and coherent), 426-28 (characterization of legislative purpose is act of creation rather than discovery), 428 (unrealistic to expect legislative rather than judicial response to changed circumstances), 428-32 (Congress enacts a statute's words, not its legislative history or "intent"), 433 (difficult to aggregate the "intentions" of a multimember body), 445 (requiring judicial deference to all agency interpretations of law ignores legislative distrust of agency discretion), 449-50 (understanding statutes as deals is problematic because public officials often respond to their own conception of the public interest, multiple forces are involved in producing a statute, and pluralist systems reflect collective action problems, strategic behavior, cycling, and other difficulties). 
complete and fictive nature of the enterprise of interpreting texts leads him astray in two ways. He employs inappropriate criteria to reject other interpretive systems, and he fails to subject his own system to the correct evaluative criterion: whether the principles of construction in use allow judges and legislators to cooperate effectively in making and applying legal norms.

In Part II we critique Sunstein's canonical approach to statutory interpretation as a system intended to avoid recourse to fiction in the ascertainment of statutory meaning. While we accept the value of Sunstein's analysis of the effects pathologies have on the statutory regimes agencies implement, we believe that Sunstein's remedies require the adoption of new interpretive fictions even more intractable than those employed by traditional modes of statutory construction. The choice of fictions is not, as Sunstein suggests, a simple matter of applying the social science literature of one's choosing to the legal process. Sunstein, we believe, fails to consider the distortions imposed by the fictions he has chosen.

\section{Fiction and Statutory Construction}

\section{A. Interpretive Fictions}

The business of statutory interpretation consists in giving meanings to words, a task more difficult than it sounds. Much twentieth-century scholarship in philosophy, literary criticism, linguistics, and psychology has focused on the problem of meaning and the mysterious process by which it is infused into what are now fashionably called "texts." Here we only intend to make use of a few notions that we believe have become common intellectual property as a result of this "textual revolution."

As an initial premise, then, we may say uncontroversially that the meaning of words depends largely on social context. ${ }^{11}$ This is no less true of complex written instruments than it is of the simple verbal expressions of everyday life. We join with others in social practices and share beliefs reinforced by those practices, thus we can refer to a common context that gives meaning to statements of or pertaining to those practices. A shared appreciation of team sports, for example, allows newspaper readers to absorb the rheto-

\footnotetext{
11 "Social context" should be distinguished from "linguistic context," which refers to the words surrounding a particular expression. The linguistic context of this footnote is the text above it on the page; the social context of this footnote is a complex shared understanding of what it means to read a law review, and more particularly what it means to read a "commentary" on another author's law review article. As used in this article, "context" refers to the social rather than the linguistic context of language.
} 
ric of sports writing, with all its metaphors of violence and military confrontation, without believing that Sunday's football game was really the small-scale war the literal language of Monday's newspaper seems to describe.

This organizational aspect of meaning is captured in the phrase "interpretive community."12 The interpretive community, for our purposes, is simply the social group whose shared comprehension of a context makes possible the common interpretation of socially relevant texts. The group element is absolutely necessary to the interpretive process. If the context in which each reader functions is too idiosyncratic-devoid of shorthand reductions of experience portable enough to be shared-"meaning" is threatened.

The context shared by members of the interpretive community is more than a consensus about facts. The context underlying our comprehension of the sports page is not merely a factual agreement about football games (a consensus as to the rules, the conditions of participation, etc.); it is a complex combination of beliefs, myths, and rituals concerning football. The community interprets the symbolism of the sports page not solely by reference to facts on which the community agrees, but also in relation to other symbols which the community holds in common. Understanding those other symbols, which we may call the culture of football, is a necessary precondition to the successful interpretation of the sports page.

Because symbolic elements of context play a strong role in the process of interpretation, the "meaning" of a public statement or action may rest on folklore or beliefs that have no basis in fact. In connection with the celebration of Washington's birthday, for example, we correctly construe depictions of a cherry tree, even though most of us realize that the story linking George Washington and the cherry tree is wholly fictitious. The fictive nature of the link casts no doubt, however, on the correctness of our interpretation; indeed, the "meaning" of the cherry tree can only be ascertained by reference to a widely shared belief.

In the instance of the cherry tree and Washington's birthday, the fictive nature of the interpretive context is taken for granted by all interpreters-the fable has been around at least since Par-

12 The phrase "interpretive community," and its most comprehensive definition (somewhat different from the one implied here), is found in the work of Stanley Fish. See generally Stanley Fish, Is There a Text in this Class? The Authority of Interpretive Communities 338-55 (Harvard, 1980). 
son Weems, ${ }^{13}$ and its invocation is automatic rather than a concerted attempt to understand the otherwise ambiguous symbol of the cherry tree. But sometimes it is necessary for us to create fictive contexts deliberately in order to understand complex and ambiguous events. The purposive invention of stories about the world arises precisely from our need for a common context.

Simplified models of the world, even if based on deliberate falsehoods, inevitably become part of the technology of meaning. For example, when emancipated slaves referred to Abraham Lincoln as Moses, leading his people out of captivity, they gave explicit voice to a fictionalized context in which the Emancipation Proclamation could be understood. To those outside the interpretive community, the "meaning" of the Emancipation Proclamation predicated on this fiction may seem impossibly partial or just plain wrong. But the fiction "Lincoln as Moses" was of great value to the community that created it, for it made possible the understanding of an event so complicated and ambiguous as otherwise to defy comprehension. ${ }^{14}$ The more complex the actual context of a communicative act the more likely it is that the act will be interpreted through recourse to a conventionalized or fictionalized context that is simple enough to be shared by all the relevant recipients of the communication.

At the same time that the fiction performs this invaluable function of making interpretation possible, it also excludes certain interpretations that are inconsistent with the central metaphor. Explanations based upon expediency, cynicism, or even ambivalence in Lincoln's approach to emancipation are now impossible within the interpretive community that created the "Lincoln as Moses" fiction. Such interpretations cannot be ventured precisely because the community no longer has a shared context in which they could be understood; they have become literally "meaningless."

These contextualizing stories about the world are what we mean by the phrase "interpretive fictions." Interpretive fictions are conventionalized descriptions that make communication comprehensible by providing a common basis for the social process of in-

${ }^{13}$ Mason L. Weems, The Life of Washington 11-12 (Belknap, 1962) (first published 1800).

14 See Leon F. Litwack, Been in the Storm So Long: The Aftermath of Slavery 529 (Random House, 1979). For an illuminating example of the deliberate use of the fiction of interpretation by an outsider to the interpretive community, consider Andrew Johnson's speech to the black people of Nashville after Lincoln's assassination, promising that "unworthy as I am, if no better shall be found, I will be your Moses." Id. 
terpretation. Many if not most interpretive fictions recount a stylized view of the speaker or main participant. After all, it is the context of the speech or event that goes far to "explain" its meaning. In some circumstances the conventionalized or fictionalized reality will be made explicit in the process of interpretation, as in the case of the "Lincoln as Moses" metaphor. But in other instances the stylized view of the world remains implicit and can only be glimpsed through the interpretation itself.

When interpretive fictions are invoked implicitly, they can generate rules for understanding speech. It is in this sense that interpretive fictions become not primary but secondary instruments, machine tools in the technology of meaning. The process by which fictions are formalized into rules of interpretation can be simple and immediate. For example, we depict the used car salesman in a widely-shared interpretive fiction as a trickster and a confidence man whose business is the deception of the unwary. From the creation of the fiction to the rule of interpretation ("never believe what a used car salesman says") is but a single easy step. But the process of formalization is not always so easy, or so complete. For many purposes the fiction need not be formalized at all. The impulse to create rules of interpretation is not uniformly strong throughout the culture, and there are comparatively few occasions of interpretation that are thought to require the elucidation of a comprehensive set of interpretive rules.

In the environment of the law, on the other hand, we consider rules of linguistic interpretation highly desirable. But the source of canons of construction, like other rules of interpretation, remains fiction. And in the concept of the canons we meet the juncture between the fictions of interpretation and the fictions of the law.

\section{B. Legal Fictions}

As commentators have observed at least since the time of Blackstone and Bentham, the common law has been particularly fertile in the creation of pretenses for the resolution of legal problems. These "legal fictions" operate by altering or presuming the facts of lawsuits rather than by explicit amendment of the rules of law that would otherwise apply to the particular dispute. ${ }^{15}$ Each fiction has a subject matter, comprised of the premise or

\footnotetext{
${ }^{18}$ For a general discussion of the role of fiction in the history of common law theory, see Eben Moglen, Legal Fictions and Common Law Legal Theory: Some Historical Reflections, 1989 Tel-Aviv U Stud L - (forthcoming). See also Lon L. Fuller, Legal Fictions (Stanford, 1967).
} 
premises maintained by the law without regard to their factual truth in any given lawsuit. For example, fictions may address the parties' status or their prior transactions in the case before the court, or the existence or relationship of third parties, places, or things not before the court. Fictions may also assert facts about the tribunal. For example, the court itself becomes the subject matter of fiction when the King is said to be always in it. ${ }^{16}$ And when the plaintiff states in his pleading that the island of Minorca is located within the parish of Mary-le-Bow in the ward of Cheap in the city of London, the subject matter of the fiction is obvious. ${ }^{17}$

Legal fictions can be invoked either explicitly or implicitly. The explicit invocation of a fiction involves the formal declaration-in pleadings, judicial opinions, or other parts of the documentary record-of false statements of fact that are given significant legal effect. The implicit invocation of a fiction, by contrast, attaches legal consequences to inferences from a spurious factual premise not disclosed in the language of the opinion or pleading. The plea that Paris is located in London is the simplest possible example of an explicit fiction. The traditional immunity of the British government in tort is an example of a rule based on an implicit fiction; it rests on the premise (often taken for granted rather than stated in the cases) that "the King can do no wrong."

10 See William Blackstone, 1 Commentaries on the Laws of England 260 (Chicago, 1979) (originally published 1765). This fiction begins in a story explaining the role of the royal judges, who are said to be merely the corporeal evidence of the King's presence. But the fiction of the King's presence, serving at first a symbolic purpose, comes to have operational effect. Because the King is always present in court, he can never suffer a default judgment. Id. Here, the story developed into a legal fiction because the presumed fact of presence has legal consequences attached to it. The effect is to premise a legal rule (the government never defaults) on what is in this instance a specious factual foundation (the King is actually in his courts).

${ }_{17}$ The goal of this surprising statement, which seems to have been perfectly acceptable and entirely incontrovertible in the fifteenth century, is to establish venue and avoid choice of law difficulties in cases involving bills of exchange made abroad and payable at home. See YB Mich 15 Ed IV, f 14, pl 18 (1576) (Calais in Kent); YB Pasch 20 Hen VI, f 28, pl 21 (1443) (Paris in London).

${ }^{18}$ This fiction has a particularly rich and extensive history which, like the fiction that the King is always in court, begins in a quasi-mystical expression of royal greatness. To this expression legal consequences attach. If the King can do no wrong, then he cannot be supposed to have authorized or ratified wrongs done by his agents, thus neither he nor his servants are answerable for their torts. Therefore it becomes possible to determine authoritatively that, although the Crown may be sued on its contracts, there can be no entitlement to recovery by a shipowner whose vessel was burned by the Royal Navy off the coast of Africa on the mistaken impression that it was engaging in the slave trade. Tobin $v$ The Queen, 143 Eng Rep 1148 (CP 1864). See also Feather $v$ The Queen, 122 Eng Rep 1191 (KB 1865) (suit for patent infringement will not lie against servants of Crown because Queen can do no wrong). For a brief general review of this fiction's history, see Peter H. Schuck, Suing 
Then there are the largely implicit fictional assumptions that judges make about the group behavior of legislators that are and have been the foundation of judicial interpretation of legislative documents. The fundamental fiction, one so broad as to escape being primarily legal at all, may be called the fiction of collective intent. Courts have always supposed that the group of individuals clothed with the authority to make statutes possesses a specific intention attributable to all the individuals who voted in favor. ${ }^{19}$ Kenneth Arrow, generalizing an illustration suggested by Condorcet, has proven the fictional nature of this universal judicial supposition..$^{20}$

The methods available for divining collective intent require even further resort to the patently untrue. The modern American approach, to which we have grown so inured that its strangeness no longer strikes the eye, is to presume that legislators have a meaningful connection to the mass of official-looking printed material commonly known as "legislative history." Here the subject matter of the fiction is implicit. It is the proposition that legislators read, or are at least conversant with and vote on the basis of, the facts and arguments contained in committee reports, hearing transcripts, and floor debates. Only slight acquaintance with the process is necessary to discover incontrovertible evidence that most legislators are ignorant of the overwhelming majority of "legislative history." Frequently, they are entirely unaware of the literal content of the statute itself.21

The modern fiction of legislative history is not the only fictive device spawned by the problem of collective intent. The long line of English cases construing new enactments in pari materia with

Government 30-35 (Yale, 1983).

10 For a particularly ironic example of the early use of this interpretive fiction, consider the response of one fourteenth-century royal judge to counsel's attempt to put an unwelcome construction on a statute with whose passage the judges on the Bench, by virtue of their presence in Parliament, had been concerned: "Do not gloss the Statute; we understand it better than you do, for we made it." Aumeye v Anon, YB Mich 33 Ed I, 78, 82 (1305).

${ }^{20}$ See Kenneth Arrow, Social Choice and Individual Values (John Wiley \& Sons, 1951); M. le Marquis de Condorcet, Essai Sur l'Application de l'Analyse à la Probabilité des Décisions Rendues à la Pluralité des Voix (Chelsea, 1972) (originally published 1785).

${ }^{21}$ For a remarkably courageous example of realist statutory interpretation along these lines, see the dissenting opinion of Justice Stevens in Sorenson v Secretary of the Treasury, 475 US 851, 866-67 (1986), which concludes Congress had no intention with regard to an obscure provision of the Omnibus Budget Reconciliation Act of 1981, a "vast piece of hurriedly enacted legislation." See also Neal E. Devins, Appropriations Redux: A Critical Look at the Fiscal Year 1988 Continuing Resolution, 1988 Duke L J 389, 399 (due to time constraints, the vast majority of members of Congress did not have an opportunity to read the 2,100-page appropriations resolution prior to vote). 
prior legislation on the same subject is also the product of fiction. ${ }^{22}$ It is sometimes suggested that such construction is possible because Parliament is eternal and speaks with one voice. It is also suggested, more naturalistically, that the members of the legislature are presumed to act in full knowledge of the existing state of the law..$^{23}$ While the implicit subject matter of the fiction is thus variable, the resort to fiction is recurrent.

Systems of statutory interpretation also rest on legal fictions. For example, Hart and Sacks ${ }^{24}$ did not urge judges to attribute an internally consistent set of public-regarding purposes to Congress because they actually believed that Congress behaves in a manner consistent with their interpretive system. They understood that Congress is not always coherent, that different members vote for statutes to further different purposes, that those purposes are often inconsistent, and that some of the purposes are to advance private interests. ${ }^{25}$ Hart and Sacks urged their interpretive approach because they believed that judges are likely to create results more appropriate to the judicial function and to the legal order if they interpret statutes in a manner intended to further some set of internally consistent, public-regarding purposes ascribed to Congress. ${ }^{26}$

Like other interpretive regimes, the Supreme Court's approach in Chevron is premised on a series of fictions. The Court concluded that agencies should have the dominant role in interpreting ambiguous agency-administered statutes because: (1) Congress has delegated this power to agencies; and (2) the politically accountable President will control those policy decisions Congress

${ }^{22}$ The classic expression of the approach is Lord Mansfield's: "Where there are different statutes in pari materia though made at different times, or even expired, and not referring to each other, they shall be taken and construed together, as one system, and as explanatory of each other." The King $v$ Loxdale, 1 Burr 445, 448 (KB 1758) (emphasis in original). See Fortunatus Dwarris, A General Treatise on Statutes 699-701 (Littell, 1835).

${ }^{23}$ See The Queen $v$ The Inhabitants of Watford, 115 Eng Rep 1413 (QB 1846); Jones $v$ Brown, 154 Eng Rep 519 (Exch 1848); Barlow v Teal, 15 QBD 403 (1885); Ex parte the County Council of Kent, 1 QBD 725 (1891).

24 Henry M. Hart, Jr. and Albert M. Sacks, 2 The Legal Process 1148-79 (Cambridge, tent ed 1958).

${ }^{25}$ Id at 937, 949-50 (proponents of licensing statutes and food standardization rules often are motivated by desire to restrict competition).

28 Thus, Hart and Sacks consistently refer to "the purpose which ought to be attributed" to Congress in enacting a statute. Id at 1153, 1157 (emphasis added). They explain the basis for their interpretive system by reference to the goals of the legal system, rather than the goals of Congress: "The idea of a statute without an intelligible purpose is foreign to the idea of law and inadmissable." Id at 1156. 
has declined to make through his control over the agencies. ${ }^{27}$ Both premises are fictional in most cases. The modern phenomenon of divided government has added constant partisan rivalry to the preexisting institutional rivalry between the politically accountable branches. ${ }^{28}$ In this political environment, Congress rarely "intends" to give the President greater policymaking power. Even when Congress does intend to give the President policymaking power, the President rarely exercises that power. ${ }^{29} \mathrm{He}$ is not even aware of most of the interpretive disputes agencies resolve.

We have no quarrel with Sunstein's characterization of the Cheuron regime as premised on fictions. ${ }^{30}$ No method of statutory interpretation can be rejected on that basis, however, because all interpretive regimes are built on a series of fictions. Chevron must stand or fall on bases independent of the factual or fictive nature of its formal premises. An incomplete list of legal realist premises for Chevron might include the following: ${ }^{31}$

(1) If Congress recognizes that ambiguous statutory language increases the President's power, Congress is less likely to choose ambiguous language;

(2) If the electorate believes that the President has the power to control agency policy decisions, it is more likely to hold the President politically accountable for those decisions. This, in turn, will increase the President's incentive to exercise control over policymaking in the administrative state to the extent that Congress has left policy decisions open;

${ }^{27}$ See Chevron, 467 US at 865-66:

Judges ... are not part of either political branch of the Government. ... In contrast, an agency to which Congress has delegated policy-making responsibilities may, within the limits of that delegation, properly rely upon the incumbent administration's views of wise policy to inform its judgments. While agencies are not directly accountable to the people, the Chief Executive is, and it is entirely appropriate for this political branch of Government to make such policy choices. ...

${ }^{28}$ See Richard J. Pierce, Jr., Morrison v. Olson, Separation of Powers, and the Structure of Government, $1988 \mathrm{~S}$ Ct Rev 1, 40-41; Lloyd N. Cutler, Now Is the Time for All Good Men ..., 30 Wm \& Mary L Rev 387 (1989); James L. Sundquist, The Question Is Clear, and Party Government Is the Answer, 30 Wm \& Mary L Rev 425 (1989).

29 See Pierce, 64 NYU L Rev 1239 (cited in note 9).

so Sunstein, 103 Harv L Rev at 445, 503 (cited in note 1). See also Antonin Scalia, Judicial Deference to Administrative Interpretations of Law, 1989 Duke L J 511, 517 (Chevron, like any other rule adopted in this field, is fictional).

"1 For more complete treatments, see Pierce, 41 Vand L Rev 301 (cited in note 9); Peter L. Strauss, One Hundred Fifty Cases Per Year: Some Implications of the Supreme Court's Limited Resources for Judicial Review of Agency Action, 87 Colum L Rev 1093 (1987); Pierce, 36 Am U L Rev 391, 407-17 (cited in note 9); Jerry L. Mashaw, Prodelegation: Why Administrators Should Make Political Decisions, 1 J L Econ \& Org 81 (1985); Pierce, 64 Tex L Rev 469 (cited in note 9). 
(3) Agencies are better positioned than courts to "update" statutes to reflect the latest scientific developments and prevailing political values to the extent ambiguous statutory language permits such updating;

(4) Agencies usually are better positioned than courts to identify regulatory pathologies and to adopt statutory interpretations that will counteract those pathologies;

(5) A single agency charged with responsibility to implement a statute has a comparative advantage over hundreds of federal judges in furthering the legal system's goals of consistent interpretation of national statutes and coherent interpretation of functionally related statutory provisions.

This continuing resort to legal fictions as part of the technique of statutory interpretation is somewhat less surprising when considered in relation to the general social tendency to establish interpretive fictions in all areas of social life. The legal fictions of statutory interpretation are also, in the formal sense, interpretive fictions. Their purpose is to create a context in which the communications of the legislative process, known as statutes, can be understood by members of the interpretive community of the law.

These interpretive fictions take the form of fictive accounts of the speaker, in this case the legislature. The choice among competing fictions must be based on an understanding of the complicated characteristics of the speaker and of the interpretive community. As changes occur in either, or as we gain a better understanding of the characteristics of either the speaker or the interpretive community, we should reevaluate our choice of fictions. The weight given to legislative history in contemporary statutory interpretation is based on an interpretive fiction that associates individual legislators much more closely with the product of legislative staff work than is justified by the facts. Thus, the movement away from reliance on legislative history is premised in part on changed perceptions of the dominant characteristics of the speaker. ${ }^{32}$ The move-

\footnotetext{
${ }^{32}$ See, for example, Public Citizen $v$ United States Dept. of Justice, $109 \mathrm{~S} \mathrm{Ct} 2558$, 2574-77 (1989) (Kennedy concurring) (criticizing majority for relying on selective references to legislative history of statute to support creative interpretation desired by majority); $A C L U$ v FCC, 823 F2d 1554, 1583 (DC Cir 1987) (Starr dissenting in part) (stating that judges have become "shamelessly profligate and unthinking" in their use of legislative history); Hirschey v FERC, 777 F2d 1, 7-8 (DC Cir 1985) (Scalia concurring) (criticizing assumption that details of committee reports, as opposed to broad outlines of statute's purpose, come to legislature's attention); Antonin Scalia, Speech on Use of Legislative History (delivered between fall 1985 and spring 1986 at various law schools in various forms), excerpted in Daniel A. Farber and Philip P. Frickey, Legislative Intent and Public Choice, 74
} 
ment away from Hart and Sacks's system toward an interpretive regime that confers a greater role on agencies is based in part on changes in the characteristics of the interpretive community. Over 800 judges with widely varying ideologies are unlikely to adopt consistent and coherent statutory interpretations through use of Hart and Sacks's fictions. ${ }^{\text {s3 }}$

\section{Real Legislative History}

It may be objected here, however, that a fictive context is not absolutely necessary in order to interpret legislative action. The alternative would be to attempt to understand the legislature's actions not on the basis of what we imagine it to have done, but on what it actually did. Such an approach to statutory interpretation would rest on "real" legislative history as distinguished from the current brand of imaginative literature, which is written for the most part by staffers and lobbyists and has little or nothing to do with the history of legislation.

Real legislative history seems to offer a significant escape from the problems of interpretation outlined by Sunstein. Not only does it provide the ultimate context for linguistic interpretation of statutes, it also allows the democratically-elected legislature to retain control over legislation. After all, by consulting real legislative history we return lawmaking authority to the Congress. Where language seems ambiguous, or produces counterintuitive results in individual cases, the actual occurrences that led to the inclusion of the relevant language would be dispositive.

This solution sounds appealing, but real legislative history is a practical and philosophical impossibility. On the practical side

\footnotetext{
Va L Rev 423, 454-55 (1988) (arguing that interpretive doubts should not be resolved by examining legislative intent due to constitutional ideals of "a government of laws not of men," doctrine of separation of powers, and principle that where text of statute is clear, legislative history should not be consulted); Bruce Fein, Scalia's Way, ABA J 38 (Feb 1990) (discussing Justice Scalia's negative views on the use of legislative history to interpret statutes); Alex Kozinski, Hunt for Laws' 'True' Meaning Subverts Justice, Wall St J A14 (Jan 31,1989 ) (use of imprecise statements in legislative history permits judge to implement personal sense of right and wrong); Robert A. Katzmann, Summary of Proceedings, in Robert A. Katzmann, ed, Judges and Legislators: Toward Institutional Comity 162, 170-75 (Brookings, 1988) (discussing Justice Scalia's argument that legislative history is malleable to any purpose). See generally Frank H. Easterbrook, Statutes' Domains, 50 U Chi L Rev 533 (1983) (use of statutory construction is only proper when statute directly addresses problem or bestows power of revision on judges). But compare Farber and Frickey, $74 \mathrm{Va} \mathrm{L}$ Rev at 424-25 (discarding legislative history would deprive judges of useful tool).

3s See Strauss, 87 Colum L Rev at 1105, 1117 (cited in note 31); Neil K. Komesar, $A$ Job for the Judges: The Judiciary and the Constitution in a Massive and Complex Society, 86 Mich L Rev 657, 662-63 (1988).
} 
there lies the task of exhaustively documenting the complex reality that is the legislative process. Must a transcript of every telephone call, every lunch-table conversation with a lobbyist, and every armtwisting message from the White House or the Democratic National Committee chairman be available to explain why Congress employed a particular verbal subterfuge to render indistinct the politically charged consequences of pending legislation? Just the documentation of the public portion of the legislative process, if exhaustively undertaken, is a daunting task. Even after a century of time has passed, the issues have been clearly identified, the letters and speeches of individuals have come to rest in archives where they can be calmly inspected, and the passion of political drama has dimmed, understanding the historical environment of complex legislation remains a frightfully difficult task. ${ }^{34}$

The practical obstacles to determining the reality of the legislative process, however, are merely a clue to the deeper intractability of the enterprise resulting from the inherent indeterminacy of the historiographic process itself. Lord Acton's notion of "absolute history" has no adherents in the contemporary world. ${ }^{35}$ Indeed, most historians and philosophers of history agree that a complete account of the causal sequence of events in the past is beyond the capacity of historians. The contemporary consensus is probably closer to the idea that narrative structures used to explain the past are themselves artificially constraining, and that history, however undertaken, is largely the process of imposing cultural conventions of interpretation on the resistant surface of accessible factual detail. ". "Real" legislative history cannot be complete because no his-

34 Take for example the history of the Interstate Commerce Act. Although the "legislative history" of the ICA was available throughout the twentieth century, this by no means resolved the conflict among historians over the political origins of railroad regulation. Not until the 1960s did historians begin to consider the possibility that the railroads, far from opposing the institution of federal regulation, might have sought regulation as a financially attractive alternative to competition. This interpretive possibility resulted in the search for, and discovery of, new sources of the ICA, and a correspondingly significant reinterpretation of the statute and its origins. See Gabriel Kolko, Railroads and Regulation, 1877-1916 (Princeton, 1965). Nor was this reinterpretation in the 1960s the end of the search for the "real legislative history" of the ICA. In 1989-over 100 years after passage of the ICA-a team of researchers concluded that ICA was motivated by a desire to discriminate against long-haul shippers in favor of short-haul shippers. Thomas W. Gilligan, William J. Marshall, and Barry $\mathrm{R}$. Weingast, Regulation and the Theory of Legislative Choice: The Interstate Commerce Act of 1887, 32 J L \& Econ 35 (1989).

ss See generally John Emerich Edward Acton, Lectures on Modern History (Macmillan, 1906). See also Edward Hallett Carr, What Is History? 15-16 (Knopf, 1962).

se For an extended investigation of the relation of literary conventions and patterns of historical explanation, see Hayden White, Metahistory: The Historical Imagination in 
tory is complete. Even if every ambiguous invocation of statutory text could be resolved by the record of legislative deliberation, the inherent indeterminacies of the historical process would render some cases hard precisely because the resolving power of historiography would not be great enough to recover the necessary evidence.

\section{Fiction and Indeterminacy}

The thought experiment with real legislative history is not wasted, however. Our failure warns us that the relationship among the adjectives used by Sunstein to criticize existing styles of statutory interpretation ("incomplete," "indeterminate," and "fictional") is more complex than Sunstein recognizes. Fiction is a response to the indeterminacy problem: if we cannot ascertain the actual facts that lie behind words, we can at least agree on a story about the origin of those words that permits consistent interpretation under most circumstances. Sunstein views fiction and indeterminacy as unrelated evils that can beset a system of statutory interpretation. He demands instead a process of interpretation that is "complete" (in the sense of providing an exclusive procedure for resolving all disputes concerning the meaning of statutory language) without resort to conventions or consciously false narratives about legislative behavior.

In this sense even real legislative history is incomplete. As Sunstein himself shows, an exhaustive knowledge of the legislature's past actions and the legislators' past intentions will not resolve all cases because later circumstances in the statute's application are concededly ones about which no legislator ever thought. ${ }^{37}$ And as discussed earlier, real legislative history could not overcome the problem of indeterminacy either; it only forces us to perceive that indeterminacy is a characteristic of history, not merely a characteristic of some contemporary theories of statutory interpretation.

The only solution to the joint problems of incompleteness and indeterminacy is fiction, and it is to the building of interpretive fictions that all writers on the subject of statutory interpretation, including Sunstein, devote their time. What is objectionable about Sunstein's approach is that he fails to admit the inevitable admixture of fiction in the composition of his interpretive norms. The

87 Sunstein, 103 Harv L Rev at 426, $432 \mathrm{n}$ 96, 433-34 (cited in note 1). 
consequence is that he does not justify his canons as fictions using the appropriate criterion - their usefulness. Rather, he attempts to establish on formal grounds that his norms evade the application of his pejoratives, because they are neither incomplete, indeterminate, nor fictional. When Sunstein's canons are viewed realistically, with their fictive elements acknowledged rather than disowned, the focus shifts to whether they are in fact useful as fictions. On this more intensely practical ground his fictions are readily found wanting. To that proposition we now turn.

\section{Sunstein's Fictions and Canons of Construction}

Sunstein's canons of construction are an appeal to a shared community of interpretation and are based on distinct fictions of interpretation. Analysis of those fictions illuminates the genesis of Sunstein's canons of construction but also provides some basis for discomfort with the practical application of his canons.

\section{A. Sunstein's Stories About Government}

Like the traditional canons of construction, Sunstein's are based. on interpretive fictions that primarily depict the workings of Congress. The fictions are necessary in order to establish a shared concept of the speaker whose speech is the Statutes at Large. What distinguishes Sunstein's fictions from the ones underpinning the traditional approaches to statutory construction is Sunstein's unflattering depiction of the legislature ${ }^{38}$ Sunstein's principles of statutory construction are explicitly based on a caricature of the legislature's pathologies rather than its excellences.

The particular focus of Sunstein's interpretive fictions is Congress's failure to adhere to the principles of civic republicanism. Sunstein's fictions paint the following picture. The legislature frequently engages in the manufacture of preferences for favored individuals and groups. It often magnifies the advantages that large organizations or groups of organizations already enjoy when they confront loose aggregations of consumers, homeless people, children in need of welfare support, and other social groups crippled by relatively high organization and information costs. It also fails

\footnotetext{
38 So far as we are aware, interpretive systems predicated on pathological caricatures of legislatures are a product of the 1980s. See William N. Eskridge, Jr., Politics Without Romance: Implications of Public Choice Theory for Statutory Interpretation, $74 \mathrm{Va} \mathrm{L} \mathrm{Rev}$ 275, 278-79 (1988); Jonathan R. Macey, Promoting Public-Regarding Legislation Through Statutory Interpretation: An Interest Group Model, 86 Colum L Rev 223 (1986); Frank H. Easterbrook, Foreword: The Court and the Economic System, 98 Harv L Rev 4 (1984).
} 
to acknowledge its responsibility for difficult value choices when it constructs administrative machinery, sometimes abdicating to agencies difficult choices that cannot be comfortably resolved in the political arena. Sometimes it fails in the opposite manner, hobbling sensible public-regarding administrative schemes with irrational restrictions (such as the Delaney Clause ${ }^{38}$ ).

In characterizing these views as interpretive fictions, we are not saying that Sunstein's positions are false, or even that he has made them up. There is much basis of truth in them. More importantly, the insights, whether true or not, are widely shared..$^{40}$ It is this broad degree of general acceptance that makes the stories plausible candidates for the role of interpretive fictions. But like all interpretive fictions, the rules of interpretation that they generate are incomplete. The fictions exclude possible interpretations of reality, not because such interpretations are impermissibly in conflict with the substantive reality the fictions represent, but rather because they are inconsistent with the purely stylistic elements of the fictions.

As a central example, let us take one of Sunstein's stories about legislative pathology. A key element of his approach is that any given area of the administrative state (for example, environmental regulation) has a single operative pathology. In Sunstein's story, producers of pollution are organized and consumers of pollution are individuals who cannot easily overcome collective action problems; thus legislation will be written in a sneakily pro-polluter fashion. The proper interpretive rule, based on this story, is Sunstein's canon $3(\mathrm{~b})$, that environmental statutes should be interpreted "aggressively." 11

But, of course, it is possible to imagine an environmental statute that results not from this confrontation between organized polluters and disorganized consumers, but from a naked preference granted to one industry in the form of overaggressive environmental regulation of its competitors. The sort of legislature Sunstein describes certainly could produce such a result. That legislative body, like the human body to which it is compared, can suffer from

39 21 USC § 348 (c)(3)(A) (1988), discussed in Sunstein, 103 Harv L Rev at 422-23, 49697 (cited in note 1); see text at notes 51-58.

40 For excellent general discussions of public choice theory and the legislative process, see Jerry L. Mashaw, The Economics of Politics and the Understanding of Public Law, 65 Chi Kent L Rev 123 (1989); Symposium on the Theory of Public Choice, 74 Va L Rev 167 (1988); Daniel A. Farber and Philip P. Frickey, The Jurisprudence of Public Choice, 65 Tex L Rev 873 (1987).

4I Sunstein, 103 Harv L Rev at 478 (cited in note 1). 
several illnesses at once. Sunstein's interpretive fiction, however, focuses on a single pathology at a time, and the canons of construction are organized accordingly, following not the logical structure of the world as described by the interpretive fiction, but rather the interior literary logic of the fiction itself. As we show below, that several legislative pathologies may plague the same legislative enactment is a problem to which Sunstein has not been attentive, despite the plethora of real-world examples. The reader may conclude that the root of the problem lies in the ease with which interpretive fictions acquire, like legal fictions, operational consequences. Rather than merely summarizing reality, their conventionalizing power comes to define reality in ways that make a difference.

\section{B. Sunstein's Canons and the Interpretive Community}

Like all other interpretive fictions, Sunstein's serve to define the boundaries of the community of belief, because only those accepting the fictions as legitimate schemata of reality form the interpretive community. Thus statutory interpretations based upon particular fictions are convincing only to those for whom the fiction represents a reasonable, if compressed, representation of the context. Not all onlookers, after all, thought Abraham Lincoln a Mosaic figure. Sunstein's fictions appeal to believers of what he and others have called liberal republicanism. They also conform to a certain kind of institutionalized distrust of Congress that has steadily gained ground in American public opinion in the past thirty years. Sunstein's fictions will not necessarily appeal to all the members of the interpretive community, however, which for operational purposes Sunstein equates with the 800-plus members of the federal judiciary. ${ }^{42}$

C. Ambiguity, Legislative Supremacy, and the Power of Sunstein's Canons

It is important to note just how much power the interpretive community adopting Sunstein's canons will have. Before describing the proposed canons, we consider the role Sunstein urges for the canons. He says that his canons should control judicial interpreta-

\footnotetext{
42 Sunstein recognizes that the interpretive community includes agency administrators. Sunstein, 103 Harv L Rev at 413 (cited in note 1). Consistent with his rejection of Cheuron, however, he focuses his discussion almost entirely on judges.
} 
tion of agency-administered statutes only in cases of ambiguity.43 Consistent with this limited purpose, Sunstein pays frequent homage to the principle of legislative supremacy. ${ }^{44}$ The principle of legislative supremacy, however, causes more trouble for Sunstein than he seems willing to admit.

Anyone proposing canons of construction must ultimately be prepared to explain whether these canons are binding upon the legislature. To assent to the principle of legislative supremacy is to admit that the legislature is not bound by the canons. If Sunstein is to retain belief in legislative supremacy as a feature of his system, therefore, he must anticipate the hard case in which Congress chooses to pass legislation embodying its own canons, contradicting those selected by Sunstein. If Congress passes a statute proclaiming that environmental regulations are to be interpreted narrowly by the courts, is that congressionally selected canon determinative in the interpretation of future statutes? Or is the congressional decision to enact this anti-canon an expression of "legislative pathology" that the courts ought to "correct"? The status of the canons as a species of meta-legislation conceals a conflict between the act of canon-making and the belief in legislative supremacy, but only so long as Congress refrains from expanding the general principles of construction embodied in the first title of the United States Code to embrace the matters discussed by Sunstein.

In order to finesse this difficulty, Sunstein limits his canons to the resolution of statutory "ambiguity." In the merely ambiguous statute, after all, Congress has not created the conflict over interpretive rules that strains the commitment to legislative supremacy. But the intellectual constraint involved in applying the canons only in areas of ambiguity is too severe for Sunstein to abide by for long. His illustrative examples of the canons' operation are inconsistent with the modesty of the claim. He uses his canons both to find ambiguity where it does not otherwise exist and to resolve the ambiguity so found.

Sunstein returns repeatedly to two interpretive disputes to illustrate the manner in which the canons would operate. ${ }^{45}$ In Industrial Union Dept. v American Petroleum Institute ("Ben-

43 Id at 464.

4 Id at $424,434,456,460,465-66$. For an excellent discussion of the meaning and importance of legislative supremacy, see Daniel A. Farber, Statutory Interpretation and Legislative Supremacy, 78 Georgetown L J 281 (1989).

4s Sunstein, 103 Harv L Rev at 419, 423, 458, 478, 480, 489-92, 494, 496-97 (cited in note 1). 
zene"), a four-Justice plurality of the Supreme Court interpreted the Occupational Safety and Health Act to require the agency to make a threshold finding that the preexisting level of exposure to a toxic substance in the workplace creates a "significant risk" to workers before the agency can impose any lower limit on the level to which workers can be exposed. ${ }^{48}$ Like other commentators, ${ }^{47}$ Sunstein is unable to reconcile the plurality's interpretation with the language or legislative history of the Act. ${ }^{48} \mathrm{He}$ concludes that the Court interpreted the statute to require a finding that Congress never required. In Justice Marshall's words, the plurality's standard bore "no connection with the acts or intentions of Congress." 49 Sunstein goes on, however, to praise the plurality for acting responsibly because its disingenuous interpretation is consistent with his proposed canons. ${ }^{50}$ In Sunstein's view, allowing the agency to regulate without first making a finding of "significant risk" would be consistent with congressional intent, but it would be wrong because it would produce bad results.

Sunstein's second illustrative case is the D.C. Circuit's decision in Public Citizen $v$ Young, ${ }^{\text {,1 }}$ interpreting the Delaney Clause, which prohibits the Food and Drug Administration (FDA) from approving the use of any color additives that "induce cancer when ingested by man or animal." tion of the Delaney Clause that permitted it to approve color additives that are weak carcinogens. The D.C. Circuit reversed that interpretation, noting that both the language of the Act and its legislative history demonstrated that Congress expressed an unambiguous intent to prohibit the FDA from approving any carcinogenic color additive no matter how weak and no matter what the circumstances.

Writing for the court in Public Citizen, Judge Williams made no secret of his desire to find an ambiguity in the Delaney Clause or of his desire to defer to the FDA's interpretation of the Act. ${ }^{53}$ Both in his opinion in Public Citizen and elsewhere, Judge Wil-

4648 US 607,642 (1980).

${ }^{47}$ See, for example, Pierce, 64 Tex $\mathrm{L}$ Rev at 475-85 (cited in note 9).

\&8 Sunstein, 103 Harv L Rev at $490-91$ (cited in note 1).

49448 US at 690 (Marshall dissenting).

so Sunstein, 103 Harv L Rev at 491 (cited in note 1).

61831 F2d 1108 (DC Cir 1987).

${ }^{52} 21$ USC $\$ 348(\mathrm{c})(3)(\mathrm{A})$. For an excellent discussion of the three parallel provisions that constitute the Delaney Clause, see Richard A. Merrill, FDA's Implementation of the Delaney Clause: Repudiation of Congressional Choice or Reasoned Adaptation to Scientific Progress?, 5 Yale J Reg 1, 3-6 (1988).

6s 831 F2d at 1113 . 
liams has expressed his strongly held views that courts should defer to agency interpretations of ambiguous statutory provisions, ${ }^{54}$ and that the absolutist philosophy underlying the Delaney Clause is bad public policy that yields bad results in important contexts. ${ }^{\text {s5 }}$ Notwithstanding his strong desire to affirm the FDA's interpretation, however, Judge Williams reluctantly concluded that Congress had unambiguously adopted a policy precluding FDA approval of any carcinogenic color additive.

Sunstein is highly critical of the D.C. Circuit's opinion in Public Citizen. ${ }^{5 B} \mathrm{He}$ argues that the court should have relied on one or more of his proposed canons both to find an ambiguity and to resolve that ambiguity in a manner that permits the FDA to approve color additives that are weak carcinogens. ${ }^{57}$ Sunstein recognizes that such an interpretation would be inconsistent with the original intent of Congress, but he argues that it would improve the performance of the regulatory system. ${ }^{.8}$

These examples illustrate the extraordinary strength of the canons Sunstein proposes. The canons would authorize a judge to add statutory requirements Congress never intended to impose and to amend or delete statutory requirements Congress did intend to impose. Allocating to judges, guided only by Sunstein's canons, this extraordinary degree of policymaking power is consistent with Sunstein's unequivocal rejection of the "judge as an honest agent" theory of statutory interpretation. ${ }^{89}$ According to Sunstein, judges cannot confine themselves to the modest role of determining and enforcing congressional intent because, notwithstanding the efforts of the Framers to create a legislative process that minimizes the likelihood of factionalism, ${ }^{60}$ the legislative process continues to

ss See, for example, Associated Gas Distributors v FERC, 824 F2d 981, 997-1001 (DC Cir 1987).

${ }^{8 s}$ See, for example, Union of Concerned Scientists v NRC, 824 F2d 108, 121 (DC Cir 1987) (Williams concurring).

so Sunstein, 103 Harv L Rev at 496-97 (cited in note 1).

${ }^{37}$ Id. Sunstein relies on his proposed canons to interpret statutes to avoid obsolescence and in favor of de minimis exceptions to support his contention that the term "induce cancer" is ambiguous. In a nutshell, he argues that Congress originally chose this statutory language based on a mistaken belief that only a few substances "induce cancer." He argues that Congress never intended to prohibit the use of the hundreds of substances that modern science has shown to be carcinogenic. See id.

ss Id at 422-23, 496-97.

so Id at 437-41, 460-62.

60 See Federalists 9 (Hamilton), 10 (Madison), 45 (Madison), 51 (Madison), 57 (Madison), 58 (Madison), 61 (Hamilton), 62 (Madison), and 73 (Hamilton), in Jacob E. Cooke, ed, The Federalist 50, 56, 308, 347, 384, 391, 410, 415, 492 (Wesleyan, 1961). See also Pierce, 64 NYU L Rev at 1248 (cited in note 9). 
perform imperfectly. Thus, judges must take responsibility to counteract the potential effects of a wide range of political and regulatory pathologies. ${ }^{61}$

\section{Sunstein's Canons in Detail}

Sunstein seems to recognize that his proposed canons are incomplete in the sense that the general principles he uses to generate the current set of canons can and should be used to extend the canons to other forms of political and regulatory pathology that he does not address. ${ }^{62}$. He promises to flesh out his canons as one component of his future research agenda. Even in their incipient truncated form, however, Sunstein's canons require judges to undertake daunting responsibilities in the process of interpreting agency-administered statutes.

Sunstein proposes three categories of canons: (1) canons derived from constitutional values; (2) canons derived from understandings of how alternative statutory interpretations will improve the performance of political institutions; and (3) canons that will enhance the performance of a regulatory regime by counteracting or avoiding the typical causes of regulatory and statutory failure. ${ }^{63}$ Each category contains a long list of canons. ${ }^{64}$ Sunstein recognizes the inevitability of conflicts among his proposed canons. ${ }^{65} \mathrm{He}$ solves the problem partly by ranking the canons according to their importance. ${ }^{66}$ Any canon in category (1) trumps any canon in categories (2) or (3), and canons within each category are rank-ordered as well. Sunstein recognizes, however, that ranking alone is inadequate as a device to resolve intercanon conflicts. In some contexts, a generically less important political or regulatory pathology may be of greater concern than a generically more important pathology. Thus, courts must harmonize the canons based "not simply on the applicability of interpretive norms, but also on the degree of their infringement." 67 While canon (1)(g) would trump canon (3)(c) in the typical case, a court should resolve the intercanon conflict in the opposite manner if it determines that a particular interpretive dispute threatens greater infringement of the value from which

\footnotetext{
B1 Sunstein, 97 Yale $L J$ at at 1544-47 (cited in note 6).

${ }^{62}$ Sunstein, 103 Harv L Rev at 467 (cited in note 1).

63 Id at 466-68.

is Id at $406,468-89$.

65 Id at 497.

68 Id at $498-99$.

67 Id at 499 .
} 
canon (3)(c) is derived than the value from which canon $(1)(\mathrm{g})$ is derived.

1. Canons based on constitutional norms.

Category (1), Sunstein's constitutional canons, ${ }^{68}$ begins with canons that are relatively uncontroversial, at least when stated as abstractions: (a) statutes should be interpreted to avoid constitutional invalidity and constitutional doubts; (b) statutes should be interpreted in a manner consistent with the assumption that states have authority to regulate their own citizens and territory; and (c) statutes should be interpreted to enhance political accountability and to preserve the system of checks and balances. ${ }^{69}$ As Sunstein notès, courts have long applied these canons, at least to some degree and in some classes of cases. The problems inherent in implementing the category (1) canons are likely to emerge from two sources-intercanon conflicts and disagreements concerning the existence and significance of some of the constitutional values that form the basis for some of Sunstein's canons.

The first source of problems can be illustrated by considering Sunstein's canon (1)(b): statutes should be interpreted consistent with "the basic assumption [] that states have authority to regulate their own citizens and territory."70 Sunstein's constitutional canons would be incomplete unless they recognized two recurrent political and regulatory pathologies inconsistent with canon (1)(b): first, the tendency of state regulation to create significant positive and negative interstate spillovers in an increasingly integrated economy, ecology, and society; second, the greater susceptibility of smaller political units to capture by factions. These two wellknown pathologies are constantly in tension with Sunstein's canon (1)(b). They can be counteracted by interpreting statutes to further the constitutional values that underlie the Supremacy Clause and the Commerce Clause.

Sunstein urges courts to invoke a clear statement rule designed to further the constitutionally recognized value of state and local autonomy: only Congress can preempt a state regulation and then only by doing so explicitly. ${ }^{71}$ It is difficult to reconcile this rule with Sunstein's description of political pathologies in Congress, however. A sufficiently deliberative and rational Con-

\footnotetext{
-s Id at 468-74.

- Id at 468-71.

70 Id at 469.

71 Id.
} 
gress would authorize federal agencies to preempt state regulations that create significant negative interstate spillovers or that are symptomatic of factionalism. Because Sunstein's judges are charged with the herculean task of interpreting statutes to avoid the effects of political pathologies, canon (1)(b) seems to require a corollary: judges should interpret federal statutes to permit federal agencies to preempt state regulations that create significant interstate harms or that are symptomatic of factionalism. The Supreme Court appears to have adopted and applied precisely such a corollary in City of New York $v$ FCC. ${ }^{72}$ Of course, in all interesting cases the canon and its corollary would conflict, and a judge would have to determine which should control. This may be the decisionmaking process Sunstein has in mind. In describing proposed canon (1)(b), he acknowledges that the clear statement principle is "no substitute for an inquiry into the relationship between state and federal law in the particular context ...."73 But if canon (1)(b) must constantly be balanced against its corollary, it is difficult to know what the canon means.

The other problem likely to arise in applying Sunstein's category (1) canons emerges upon examination of some of the constitutional values he urges courts to further through "aggressive" statutory interpretation. His constitutionally based canons do not end with the abstractly noncontroversial constitutional values listed in (1)(a), (b), and (c). Rather, they extend through five other subcategories. Each subcategory includes several canons. Some of the constitutional values furthered by the canons are not likely to be obvious to all judges. For example, in subcategory (1)(f), entitled "disadvantaged groups," Sunstein asserts the existence of a constitutional norm protecting the rights of gays and lesbians. ${ }^{74}$ In subcategory (1)(h), entitled "welfare rights," he asserts the existence

72486 US 57, 64 (1988) (If the FCC's decision to preempt state and local signal-quality regulations represents a reasonable accommodation of conflicting policies committed to the agency's care by statute, the decision should not be disturbed unless it appears from the statute or its legislative history that the accommodation "is not one that Congress would have sanctioned."). See also NCNB Texas National Bank v Cowden, 895 F2d 1488, 1494, 1498 (5th $\mathrm{Cir}$ 1990). The Court seems increasingly receptive to an interpretive approach that confers on federal agencies the power to preempt state regulations as long as the federal agency is acting within its jurisdictional limits. See, for example, Ray $v$ Atlantic Richfield Co., 435 US 151, 178 (1978); Arkansas Electric Coop. Corp. v Arkansas Public Service Comm., 461 US 375, 383 n 7 (1983). See also Richard J. Pierce, Jr., Regulation, Deregulation, Federalism, and Administrative Law, 46 U Pitt L Rev 607, 636-61 (1985); Oliver Wendell Holmes, Jr., Law and the Court, in Collected Legal Papers 291, 295-96 (Peter Smith, 1952); Federalist 10 (Madison) in Cooke, ed, The Federalist at 56 (cited in note 60).

7s Sunstein, 103 Harv L Rev at 469 (cited in note 1).

74 Id at $472-73$. 
of a constitutional right to "minimum levels of subsistence."75 $\mathrm{He}$ characterizes the many judicial decisions failing to enforce these rights as evidence that the judiciary recognizes the rights but declines to enforce them for institutional reasons. ${ }^{78}$ In each case, his answer is a canon requiring "aggressive construction" of statutes that can be interpreted to implement these constitutional rights that are currently unenforced by the judiciary.

The difficulty here lies in the less than universal acceptance of Sunstein's assertion that protecting gay and lesbian rights and providing minimum levels of subsistence are constitutional norms. More generally, judges who see in the constitution norms and values different from those Sunstein sees are likely to adopt "constitutional" canons of interpretation that differ materially from the score or so proposed by Sunstein. Judges who believe, for instance, that the Takings Clauses reflect a constitutional aversion to redistribution of wealth ${ }^{77}$ are likely to adopt dramatically different interpretations of many agency-administered statutes through Sunstein's proposed process of "aggressive construction" of statutes to further unenforced constitutional norms.

\section{Canons based on institutional concerns.}

The canons in Sunstein's second category are designed to respond to institutional concerns. ${ }^{78}$ The list of concerns and corresponding canons includes such relatively noncontroversial canons as the presumption against implied repeals and the presumption against implied exemptions from taxation. ${ }^{79}$ Many of the institutionally based canons also present serious application problems. Proposed canons (2)(e) and (2)(f) illustrate the difficulty of choosing among canons. Canon (2)(f) requires courts to presume that the legislature has not precluded judicial review of agency decisions ${ }^{80}$ It is premised on Sunstein's assertions that agencies are susceptible to factionalism and that the expectation of judicial review can deter factionalism. ${ }^{81}$ Canon (2)(e) instructs reviewing courts to defer to agency understandings of policy and fact. ${ }^{82}$ It is

75 Id at 473-74.

78 Id at $472-74$.

${ }_{77}$ See generally Richard A. Epstein, Takings: Private Property and the Power of Eminent Domain (Harvard, 1985).

7o Sunstein, 103 Harv $L$ Rev at 474-76 (cited in note 1).

70 Id at 475 .

so Id at 475-76.

sI Id at 475 .

${ }^{82}$ Id. 
premised on Sunstein's assertion that agencies are institutionally superior to courts in terms of their political accountability and their fact-finding capacity. ${ }^{83}$

It is easy to accept the premises that underlie these two proposed canons, but it is exceedingly difficult to know what courts should do in light of them. Judicial review of agency decisions always imposes costs in the form of delay and uncertainty. If courts adhere to both canons-always review but always defer to the agency-these costs represent a deadweight social loss. If courts temper their application of canon (2)(e) in light of canon (2)(f), they risk misunderstanding the facts or imposing policies that lack any source of political legitimacy. Many empirical studies of judicial review purport to document precisely this combination of effects-delay, uncertainty, misunderstanding of facts, and judicial imposition of policies with questionable political legitimacy. ${ }^{84}$

At their logical limits, canons (2)(e) and (2)(f) are opposites. Indeed, Sunstein seems to recognize this fact. In his discussion of canon (2)(e), he notes with apparent approval that "the rare judicial decisions finding agency action not subject to judicial review are based on perceptions that judicial intervention would likely be counterproductive in the circumstances." ${ }^{85}$ Does this mean that a judge who shares Jerry Mashaw's belief that judicial review of agency decisionmaking on the subjects of disabilities and highway safety is counterproductive should find that those decisions are not subject to judicial review ${ }^{98}$ We suspect Sunstein would be among the first to decry such a judicial decision. It would conflict with proposed canon (2)(f) and several of his other proposed canons. ${ }^{87}$

ss Id.

84 See, for example, Rosemary O'Leary, The Impact of Federal Court Decisions on the Policies and Administration of the U.S. Environmental Protection Agency, 41 Admin L Rev 549 (1989); John M. Mendeloff, The Dilemma of Toxic Substance Regulation: How Overregulation Causes Underregulation at OSHA 7-16 (MIT, 1988); Richard J. Pierce, Jr., Two Problems in Administrative Law: Political Polarity on the District of Columbia Circuit and Judicial Deterrence of Agency Rulemaking, 1988 Duke L J 300, 308-13; Jerry L. Mashaw and David L. Harfst, Regulation and Legal Culture: The Case of Motor Vehicle Safety, 4 Yale J Reg 257, 276-99 (1987); R. Shep Melnick, Regulation and the Courts (Brookings, 1983).

${ }^{85}$ Sunstein, 103 Harv L Rev at 475 (cited in note 1).

${ }^{86}$ See Mashaw and Harfst, 4 Yale J Reg at 312-13 (cited in note 84); Jerry L. Mashaw, Bureaucratic Justice: Managing Social Security Disability Claims 7, 185-90 (Yale, 1983); Jerry L. Mashaw, The Legal Structure of Frustration: Alternative Strategies for Public Choice Concerning Federally Aided Highway Construction, 122 U Pa L Rev 1, 29-51 (1973).

${ }^{87}$ See Sunstein, 103 Harv L Rev at 475, $479-89$ (cited in note 1). Actually, this result would conflict with all of Sunstein's canons, since his system is premised on the assumption that courts bear responsibility to counteract pathologies embedded in political institutions. 
This rhetorical question, however, helps to identify the inherent tension between canons (2)(e) and (2)(f). Judges who defer to agency resolutions of factual and policy issues have no chance of deterring agencies from engaging in factional decisionmaking. Judges who review agency actions aggressively in an effort to deter factional decisionmaking risk misunderstanding the facts, imposing policies with no democratic legitimacy, and creating policy paralysis in the politically accountable branches. ${ }^{88}$

\section{Canons based on regulatory pathology.}

Sunstein's third category of proposed canons is the most interesting. He urges adoption of a series of canons designed to counteract "statutory failure." the failure of agency-administered statutory and regulatory schemes and to interpret agency-administered statutes in a manner that will counteract any political or regulatory pathology that threatens to detract from the proper performance of an agencyadministered government program. He describes several wellknown (and a few lesser-known) regulatory pathologies and proposes a canon to counteract each.

Thus, for instance, environmental statutes should be interpreted "aggressively" because collective action problems tend to undermine implementation of environmental regulation by giving advantages to concentrated, well-organized interests over diffuse, poorly-organized interests..$^{80} \mathrm{By}$ contrast, occupational health and safety statutes should be interpreted in a manner that imposes obstacles to aggressive regulation.91 Regulation of occupational health and safety tends to be "overzealous" because collective action problems have different effects in this type of regulatory regime. The organized beneficiaries of regulation have advantages in the regulatory process that enable them to obtain excessive regulation in some contexts. According to Sunstein, the agency's realization that it is driven to excessive regulation when it chooses to regulate then induces the agency to refrain from any regulation in other contexts. ${ }^{92}$

\footnotetext{
Without judicial review of agency actions, courts cannot perform this function.

sa See sources cited in note 84. See also Stephen Breyer, Judicial Review of Questions of Law and Policy, 38 Admin L Rev 363, 393 (1986).

39 Sunstein, 103 Harv L Rev at $476-89$ (cited in note 1).

פo Id at 478 .

91 Id at 478-79.

92 Id at 489-91. Professor Mendeloff provides support for Sunstein's hypothesis that agencies may react to the potential for excessive regulation by refraining from any regula-
} 
From this sophisticated analysis of problems that have arisen in implementing regulatory statutes, Sunstein derives two canons: environmental statutes should be interpreted aggressively, while occupational health and safety statutes should be interpreted to create obstacles to excessive regulation. Sunstein uses similar reasoning to support many other canons in this category: ${ }^{93}$ (a) statutes should be interpreted to allow the President to resolve "large" questions of public policy, but also to require courts to resolve questions of law; (b) statutes should be interpreted to favor beneficiaries where collective action problems are likely to handicap the efforts of beneficiaries; (c) different statutes should be interpreted to incorporate the same substantive standards; (d) statutes should be interpreted to avoid "systemic" problems in regulation; (e) public law statutes should not be interpreted with reference to private law principles; (f) statutes should be interpreted to avoid irrationality and injustice; (g) statutes benefiting disadvantaged groups should be interpreted aggressively; (h) statutes that further nonmarket values and aspirations should be interpreted aggressively; (i) statutes that embody interest group transfers should be interpreted narrowly; (j) statutes should be interpreted to require cost benefit analysis (but not by monetizing nonmarket values); and (k) statutes should be interpreted to incorporate de minimis exceptions.

Most of Sunstein's category (3) canons are firmly rooted in empirical studies of regulatory pathology. The problem with these canons is not a dearth but a plethora of regulatory pathologies. The vast and growing literature on the etiology of regulatory failure identifies enough culprits to support dozens of additional category (3) canons. The canons so derived would instruct courts to move in a wide variety of conflicting directions. There is, for instance, a rich empirical literature that implicates judicial review as a major cause of regulatory failure. ${ }^{94} \mathrm{~A}$ canon premised on this regulatory pathology would displace all others: courts should interpret statutes to preclude judicial review or to limit severely the scope of judicial review.

tion. Mendeloff, The Dilemma of Toxic Substance Regulation at 1-3 (cited in note 84). He differs with Sunstein on the issue of the role of the courts in this process, however. Mendeloff views aggressive judicial review of OSHA standards as a major source of the failure of this statutory system. Id at 8-14.

83 Sunstein, 103 Harv L Rev at $476-89$ (cited in note 1).

ot See sources cited in notes 84 and 86 . 
It is important to pause at this point to recall Sunstein's proposed allocation of institutional responsibility for interpretation of agency-administered statutes and the extraordinary strength of his proposed canons. Sunstein does not explain his assumption that courts are institutionally superior to agencies as a source of statutory interpretations that counteract regulatory pathologies. Sunstein recognizes that agencies have significant comparative advantages over courts in their ability to gather facts and in the political legitimacy of their policy decisions. ${ }^{95}$ They would seem to have a similar advantage over courts in identifying pathologies in the regulatory schemes they are charged with implementing and in adopting statutory interpretations that counteract those pathologies.

Presumably, Sunstein would respond: "foxes should not guard hen houses." poorly motivated and are themselves the source of some regulatory pathologies, he has won the point. It hardly follows, however, that agencies usually are poorly motivated and usually are the source of pathologies in the regulatory schemes they implement. Sometimes agencies are well motivated and interpret ambiguities in the statutes they administer in order to counteract pathologies they have identified in their daily efforts to implement a statutory regime. ${ }^{97}$ Sunstein's selection of courts as institutionally superior to agencies in resolving ambiguities in the statutes they implement must be premised on one of two beliefs: either agencies usually are poorly motivated, or judges can distinguish with relative ease cases and contexts in which agencies are poorly motivated versus cases and contexts in which they are properly motivated. Moreover, he must have great confidence in one of these two beliefs, because they cause him to assign the dominant interpretive role to judges notwithstanding his recognition of agency superiority in fact-finding and policymaking. Those who do not share either of Sunstein's beliefs will continue to differ with him on the institutional issue.

Sunstein goes much further than to reject the institutional allocation of responsibility the Supreme Court announced in Chevron, however. He urges rejection of step one of Cheuron: "First, always, is the question whether Congress has directly spoken to the

ss Sunstein, 103 Harv L Rev at 475 (cited in note 1).

9s Id at $446,470$.

${ }^{97}$ Moreover, Sunstein has proposed institutional mechanisms that would reduce the probability that agencies will further factional interests. See Peter L. Strauss and Cass R. Sunstein, The Role of the President and $O M B$ in Informal Rulemaking, 38 Admin L Rev 181 (1986). See also Richard J. Pierce, Jr., Institutional Aspects of Tort Reform, $73 \mathrm{Cal} \mathrm{L}$ Rev 917, 934-37 (1985). 
precise question at issue. If the intent of Congress is clear, that is the end of the matter; for the court as well as the agency, must give effect to the unambiguously expressed intent of Congress."98 As Sunstein's discussion of Public Citizen demonstrates, ${ }^{99}$ his herculean judges need not "give effect to the unambiguously expressed intent of Congress." Rather, judicial interpretations are to be governed by the canons he has designed to counteract political and regulatory pathologies. Since many of these pathologies are rooted in the legislative process, Sunstein's adoption of a neo-republican theory of government dictates this omnipotent role for the judiciary. ${ }^{100}$

With this background, the next step is to survey the features of the world in which Sunstein's canons would govern judicial interpretation of statutes. Sunstein proposes more than a score of canons designed to counteract an equal number of political and regulatory pathologies. It would be easy to double the number of canons by developing a new canon to counteract each of the welldocumented pathologies Sunstein neglects. If a judge were omniscient, she could identify multiple pathologies that infect any agency-administered statutory scheme. Each provision of a statute is a product of multiple forces, usually including one or more pathologies. ${ }^{101}$ Different features of the same statutory scheme are the product of different combinations of pathologies. Moreover, the same agency-administered statute can be infected by different pathologies at different times because of changes in the political environment in which the agency functions. Thus, even an omniscient judge with no ideological bias would be forced to choose which of several conflicting canons should control any interpretive dispute. Of course, judges are neither omniscient nor free of ideological bias. Generally, they are bright and well-motivated, but they are mere mortals. They are also very busy mortals. ${ }^{102}$ Their caseload precludes them from engaging in extensive research to determine the combination of political pathologies that gave rise to a particular statutory provision or the regulatory pathologies that are likely to arise from time to time in agency attempts to imple-

\footnotetext{
${ }^{88} 467$ US at 842-43.

${ }^{89}$ See text at notes $51-58$.

100 See Sunstein, 97 Yale L J at 1544-47 (cited in note 6).

${ }^{101}$ See Section II.E.3.

${ }^{102}$ For instance, the average federal circuit judge participates in 382 cases annually. Federal Courts Study Committee, Tentative Recommendations for Public Comment 100
} (1989). 
ment statutes with alternative interpretations. ${ }^{103}$ Indeed, most judges have little understanding of what agencies do, of the resources they have available to perform their many responsibilities, or of the managerial and decision processes that are likely to permit them to perform their assigned tasks with the limited resources available. ${ }^{104}$

Sunstein would assign this task to hundreds of judges with widely varying ideological biases. Different judges are likely to reach different diagnoses based on the always ambiguous symptoms of political and regulatory pathology. The likelihood of diagnostic consensus, agreement on applicable canons, agreement in resolving intercanon conflicts, and consistency in resulting statutory interpretation is remote.

Moreover, as Peter Strauss has demonstrated, the Supreme Court's task of maintaining consistency in statutory interpretation grows more difficult every day. ${ }^{105}$ With every other component of the judicial system growing rapidly, the Court's inherent limit of 150 cases per year imposes severe constraints on its ability to maintain intercircuit consistency. Even intracircuit consistency is suffering significantly from the growth in the sprawling federal judiciary and from the increasing range of ideological perspectives that are now well-represented in all circuits. ${ }^{106}$ Strauss's prescription-greater deference to agency interpretations of statutes ${ }^{107}$-is the opposite of Sunstein's.

\section{E. Judicial Approaches to Sunstein's Canons}

Judges might interpret and apply Sunstein's canons in any of three ways. First, they might attempt a particularized canonical approach, identifying which canons apply to a specific interpretive

${ }^{103}$ For a rich description of the enormous increase in the workload of federal judges and the many ways judges have been forced to adapt to this change, see Richard A. Posner, The Federal Courts: Crisis and Reform 59-130 (Harvard, 1985).

104 It seems unlikely, for instance, that the judges who imposed statewide decision deadlines on Social Security disability decisionmaking knew that they were requiring Administrative Law Judges to hear forty cases per day. See Mashaw, Bureaucratic Justice at 188 (cited in note 86 ). It seems similarly unlikely that the judges who have engaged in aggressive review of some EPA programs knew that they were requiring the agency to abandon or to defer other programs that both EPA and Congress considered more important. See O'Leary, 41 Admin L Rev at 561-62 (cited in note 84).

${ }^{105}$ Strauss, 87 Colum L Rev at 1093, 1105-16 (cited in note 31).

108 See Pierce, 1988 Duke L J at 303-07 (cited in note 84); Richard J. Pierce, Jr., Public Utility Regulatory Takings: Should the Judiciary Attempt to Police the Political Institutions?, 77 Georgetown L J 2031, 2036-40, 2044 (1989).

${ }^{107}$ Strauss, 87 Colum L Rev at 1118-26 (cited in note 31 ). 
dispute and resolving any conflicts among arguably relevant canons. Second, judges might take a broader approach, viewing Sunstein's particularized canons as a nonexhaustive list of potential ways of characterizing and counteracting the many forms of political and regulatory failure. Sunstein's detailed instructions could then be reduced to a single broad canon-interpret statutes in a manner that will improve the performance of the regulatory system. Third, judges could adopt a broad approach that emphasizes the source of most political and regulatory pathologies-the potential for factionalism. As so interpreted, Sunstein's detailed instructions could be reduced to another broad canon-interpret statutes to minimize the effects of factionalism. In the next three sections, we attempt to show why none of these alternative methods of implementing Sunstein's canons offers a realistic prospect for acceptable results.

1. Sunstein's canons as detailed instructions.

The indeterminacy of the particularized version of Sunstein's approach can be seen by considering one of the examples he selects to illustrate his approach. Sunstein applauds the interpretation of the Occupational Safety and Health Act adopted by a plurality of Justices in Benzene. ${ }^{108}$ Requiring the agency to find a "significant risk" to workers as a result of exposure to preexisting levels of a toxic substance before the agency can reduce exposure levels avoids the regulatory pathology of overzealous regulation. To Sunstein, the Court rescued society from an agency bent on imposing "enormous costs in exchange for small or speculative gains."108

There are two large problems with Sunstein's description of the proper judicial role in Benzene, however. First, his account is counterfactual. On remand, the Reagan Administration's OSHAan agency never accused of "overzealous regulation"-reimposed the standard previously rejected by the Supreme Court. ${ }^{110}$ One of the many studies in the voluminous record concluded that the standard would avoid between 44 and 152 unnecessary deaths per 1,000 workers" 111 -gains that are necessarily "speculative" but not "small." The Supreme Court's synoptic demand for greater cer-

${ }^{108}$ Sunstein, 103 Harv L Rev at $489-92$ (cited in note 1).

109 Id at 489 .

110 Occupational Safety and Health Administration, Occupational Exposure to Benzene, 52 Fed Reg 34460 (1987).

111 See Jerry L. Mashaw and Richard A. Merrill, Administrative Law: The American Public Law System 101 (West, Supp 1989). 
tainty concerning the need for a regulation may have created a common regulatory pathology-seven years of delay in implementing a rule that will save hundreds of lives.

Second, many judges charged with responsibility to interpret OSHA through application of Sunstein's canons would apply different canons with dramatically different results. Indeed, using Sunstein's approach, it would be easy to "interpret" the statute not to require a finding of "significant risk" even if Congress had explicitly incorporated such a requirement in the Act. A judge could support such an interpretation through application of any combination of at least four of Sunstein's proposed canons: (1) statutes should be interpreted to favor beneficiaries where collective action problems are likely to handicap the efforts of beneficiaries; (2) statutes should be interpreted to avoid "systemic" problems in regulation; (3) statutes benefiting disadvantaged groups should be interpreted aggressively; and (4) statutes that further nonmarket values and aspirations should be interpreted aggressively. It is at least arguable that: (1) employees suffer from collective action problems relative to employers; (2) a requirement that an agency establish a clear need for each health-based rule before it imposes the rule will lead to systemic underregulation; (3) workers are members of a disadvantaged group; and (4) requiring employers to provide a work environment free of toxic substances will further nonmarket values and aspirations. Those same canons could support a judicial interpretation of the Food and Drug Act that establishes an absolute prohibition on carcinogenic color additives even if Congress repealed the Delaney Clause.

We are not suggesting that all judges would apply Sunstein's canons to OSHA and FDA in a manner that yields statutory interpretations the opposite of Sunstein's. We suspect that about half would agree with Sunstein's canonical results and about half would reach the opposite conclusion. That is our point. The interpretive approach he urges is hopelessly indeterminate.

The interpretive issues Sunstein selects to illustrate application of his canons are not unusual in this respect. Indeed, the complexity of the process of canonical interpretation and the indeterminacy of the results of that process increase considerably upon examination of other interpretive disputes. Each of the following examples, drawn from the vast universe of ambiguous regulatory statutes, introduces an additional set of problems that would vex judges charged with responsibility to apply Sunstein's canons. 
Section 111 of the Clean Air Act required the EPA to establish rules governing emissions of sulfur oxides from utility boilers. ${ }^{\mathbf{1 1 2}}$ Both the language of the Act and its legislative history were ambiguous with respect to an important policy question: must utilities install expensive scrubbers on all units, or can they use a combination of low sulfur coal and less expensive control technologies? ${ }^{113}$ Congress was so sharply divided on this issue that it chose intentionally ambiguous statutory language. The alternative to intentional ambiguity-deliberation to resolve the policy dispute-posed the risk of a stalemate, jeopardizing passage of the entire Act. ${ }^{114}$

Once Congress declined to resolve this major policy dispute through use of unambiguous statutory language, some other institution-an agency or court-had to make the policy decision through the process of statutory interpretation. At this point, Sunstein would charge a judge with the responsibility of interpreting the statute in accordance with his proposed canons. Canon $(3)(b)$ immediately comes to mind. Environmental statutes should be interpreted "aggressively" because their beneficiaries suffer from collective action problems. Because all environmental organizations favored a requirement of universal scrubbing, a judge should interpret $\S 111$ to incorporate such a requirement through application of canon (3)(b).

With more thought and research, however, the judge might find the canonical interpretation exercise more difficult. As Ackerman and Hassler have documented, the owners of high sulfur coal were the principal proponents of a universal scrubbing requirement. ${ }^{115}$ They viewed such a requirement as a means of enhancing their wealth by placing low sulfur coal at an economic disadvantage. Thus, the interpretive dispute arguably is governed by canon (3)(i): statutes that embody interest group transfers should be interpreted narrowly. Section 111 should not be interpreted to require universal scrubbing because universal scrubbing would effect a regulatory transfer of wealth to a narrow interest group. Since, however, canon (3)(b) outranks canon (3)(i), perhaps universal scrubbing should be required.

A little more thought and research will raise further questions about this result. Ackerman and Hassler purport to demonstrate

${ }^{122}$ Clean Air Act, 42 USC $\S 7411$ (1982 \& Supp 1988).

${ }^{113}$ Bruce A. Ackerman and William T. Hassler, Clean Coal/Dirty Air 48-54 (Yale, 1981).

116 Id at 54.

118 Id at 31 . 
that universal scrubbing is the "costliest possible clean air solution,"116 and that imposing a universal scrubbing requirement has the potential to harm air quality. ${ }^{117}$ This additional data suggests the applicability of canons (3)(f) and (3)(j): statutes should be interpreted to require cost-benefit analysis, and statutes should be interpreted to avoid irrationality. Thus, the judge needs to determine whether the combination of canons (3)(f), (3)(i), and (3)(j) counterbalances canon $(3)(b)$. Sunstein proposes no mechanism to accomplish this task.

The puzzle would not be complete, however, without considering another potential canonical outcome. Canon (2)(e) (courts should defer to agency understandings of law and policy) and the first half of canon (3)(a) (statutes should be interpreted to allow the President to resolve "large" questions of policy) suggest that the judge should eschew any independent attempt to interpret $\S 111$, affirming any reasonable interpretation the agency adopts. This result is inconsistent, however, with the second half of canon (3)(a), directing that statutes should be interpreted to require courts to resolve questions of law. By distinguishing sharply between questions of law and questions of policy in canon (3)(a), Sunstein seems not to recognize that many questions can be characterized as either or both. ${ }^{118}$ Thus, to solve the puzzle of $\S 111$, a judge must decide which of three combinations of canons should control: (3)(a) (second half) and (3)(b) suggest one result (aggressive interpretation); (3)(a) (second half), (3)(f), (3)(i) and (3)(j) suggest another (narrow interpretation); while (2)(e) and (3)(a) (first half) suggest a third (defer to agency interpretation).

Congress has created a new version of this puzzle in the process of enacting this year's amendments to the Clean Air Act. The amendments proposed by President Bush would have required U.S. automakers to manufacture a large fleet of experimental vehicles designed to burn methane, methanol, or ethanol in lieu of gasoline. ${ }^{110}$ Congress was sharply divided on this issue. ${ }^{120}$ The result

116 Id.

117 Id at 2, 78, 88. Ackerman and Hassler urge a canon the opposite of Sunstein's environmental canon: "In a nutshell, courts should not be quick to read the more aggressive forms of agency-forcing into ambiguous statutory language." Id at 106.

${ }^{118}$ See Pierce, 41 Vand L Rev at 304-05 (cited in note 9).

11 See Gretchen Morgenson and Gale Eisenstodt, "Profits Are for Rape and Pillage," Forbes 94, 96 (Mar 5, 1990); Robert W. Hahn, Last Gasp for Bush Clean Air Reforms, Wall St J A24 (Nov 7, 1989); Remarks at the Ceremony Transmitting to the Congress the Clean Air Act Amendments of 1989, 25 Weekly Comp Pres Doc 1135, 1136 (July 21, 1989).

120 See Sara Hansard, Hill Compromise on Clean Air Receives Gas Industry Support, Natural Gas Week 1, 6-7 (Mar 5, 1990). 
was another series of intentionally ambiguous provisions that may or may not be interpreted to require manufacture of such a fleet. ${ }^{121}$ The putative (and plausible) rationale for such a statutory mandate is to improve air quality. ${ }^{122}$ Environmental groups were not the only proponents of the measure, however. Agribusiness and the natural gas industry placed their considerable financial and political power behind this initiative because they expect it to enhance their wealth. ${ }^{128}$ Its prospects for passage, even in an ambiguous form, would have been slight without this special interest group support. Should a judge characterize a fleet of alternative fuel powered vehicles as an environmental protection measure or as an interest group transfer? A judge could write a well-reasoned opinion supporting either characterization and, hence, adopting either a narrow or an aggressive interpretation of the ambiguous statutory provisions through application of Sunstein's canons.

These two examples illustrate a general phenomenon that would bedevil any attempt to rely on Sunstein's canons. Most important provisions of regulatory statutes emerge from the process of statutory enactment because some people perceive them as serving the public good (for example, air quality) while other people perceive them as a source of private wealth. It is exceedingly difficult to enact a provision that is perceived as only one or the other. In most cases, both perceptions are entirely plausible: virtually all regulatory actions transfer wealth; many also serve a public good. A method of statutory interpretation that depends on the ability of a judge to characterize a statutory provision as either solving a collective action problem or as transferring wealth to a special interest group is premised on a dichotomy that rarely exists. To the extent that it does exist, judges have limited ability to distinguish

121 The seven-hundred-page Clean Air Amendments of 1990 contain many provisions that may have the effect of mandating manufacture of a fleet of vehicles designed to burn alternative fuels; for example, four different standards applicable to auto tailpipes at different times and in different locations, plus special provisions applicable to fleet vehicles.

${ }^{122}$ The tradeoffs among ethanol, methane, and reconstituted gasoline are complicated and poorly understood. Ethanol would reduce carbon monoxide emissions, but would increase aldehyde and nitrogen oxide emissions, increase use of fertilizer and pesticides, increase transportation costs, and increase food costs. Methane would reduce carbon monoxide emissions and ozone formation, but even small increases in leakage of raw methane into the atmosphere could exacerbate the greenhouse effect, since methane's insulating effect is twenty-five times as great as that of carbon dioxide.

${ }^{123}$ For discussion of gas industry efforts, see Natural Gas Industry Urges Ambitious Alternative Fuels Program, 124 Pub Util Fort 57 (Nov 23, 1989). For illustrations of agribusiness efforts, see Michael J. Weiss, The High-Octane Ethanol Lobby, NY Times Mag Part 2 at 18 (Apr 1, 1990). See also Rose Gutfeld, For Each Dollar Spent on Clean Air Someone Stands to Make a Buck, Wall St J AI (Oct 29, 1990). 
between transfers of wealth disguised as solutions to collective action problems and solutions to collective action problems that incidentally transfer wealth. ${ }^{124}$

2. Sunstein's canons as a general instruction to improve the performance of a regulatory system.

The current controversy over the Federal Energy Regulatory Commission's (FERC) power to order "wheeling" of electricity illustrates the difficulty of applying Sunstein's canons as a single broad instruction to interpret statutes in a manner that will improve the performance of a regulatory system. ${ }^{125}$ "Wheeling" refers to the transmission of electricity for third parties. For the past fifty years, utilities have adamantly opposed any effort by the government to compel them to provide wheeling service. Until recent years, FERC had taken the position that it lacks the power to order wheeling. ${ }^{128}$ In the last few years, however, FERC has begun to assert that power in a growing number of contexts. ${ }^{127}$ It is now considering imposition of a general obligation to provide equal access to transmission lines. ${ }^{128}$

The statute that governs FERC's power to order equal access to transmission is ambiguous and internally inconsistent. ${ }^{128}$ The Federal Power Act "fairly bristles" with concern about undue discrimination in the provision of transmission service. ${ }^{130}$ FERC could defend mandatory wheeling as an essential remedy to alleviate

224 See Pierce, $36 \mathrm{Am}$ U L Rev at 396-98 (cited in note 9).

${ }^{125}$ See, for example, Federal Energy Regulatory Commission, The Transmission Task Force's Report to the Commission (1989); Ashley C. Brown, Breaking the Transmission Logjam, 1 Elec J 14 (1988); Joe D. Pace, Wheeling and the Obligation to Serve, 8 Energy L J 265 (1987); William B. Tye, Competitive Access: A Comparative Industry Approach to the Essential Facility Doctrine, 8 Energy L J 337 (1987); Richard J. Pierce, Jr., A Proposal to Deregulate the Market for Bulk Power, 72 Va L Rev 1183 (1986).

${ }^{128}$ See, for example, City of Paris v Kentucky Utilities Co., 41 FPC 45 (1969).

127 See, for example, Utah Power \& Light Co., 45 FERC I 61,095 (1988) (utilities not allowed to merge unless they agree to wheel power for others).

${ }^{128}$ See Federal Energy Regulatory Commission, Regulations Governing Bidding Programs, 53 Fed Reg 9324 (1988) (proposed rule that would allow utilities to conduct auctions or to participate in auctions for new wholesale power supplies only if they agree to wheel for others).

120 There are actually two ambiguous and internally inconsistent statutes relevant to this issue: The Federal Power Act of 1935, 16 USC $\S 791-825 u$ (1988), and the Public Utility Regulatory Policies Act of 1978, 92 Stat 3117 (1978) (codified in scattered sections of Title 16).

130 See Associated Gas Distributors v FERC, 824 F2d 981, 998 (DC Cir 1987); see also FPC v Sierra Pacific Power Co., 350 US 348, 353 (1956) (Natural Gas Act and Federal Power Act are to be interpreted to mean the same thing, since one was patterned after the other and both were intended to respond to same set of problems). 
statutorily prohibited undue discrimination. ${ }^{131}$ Yet, the legislative history of the Act indicates that Congress explicitly declined to give FERC the power to make electric utilities common carri$\mathrm{ers}^{132}$-a power functionally similar to the power to mandate wheeling.

In broad terms, Sunstein's canons would instruct a judge to resolve this dispute by adopting the statutory interpretation that will improve the performance of the regulatory system. To make such a determination, however, a judge must make assumptions about the resolution of at least one other major interpretive dispute: whether FERC must continue to base wholesale electricity prices on embedded accounting costs or whether FERC can allow those prices to be established through a process of competitive contracting. ${ }^{13 s}$ The availability of mandatory wheeling would allow distributors and large consumers to choose among competing wholesale suppliers of electricity based on price. If wholesale prices are based on marginal cost (as they would tend to be in a competitive contracting process), giving distributors and consumers a choice among wholesale suppliers offers the prospect of an improved regulatory system. ${ }^{134}$ Distributors and consumers would be encouraged to purchase electricity from sources that use the least amount of society's scarce resources. Permitting distributors to choose among competing suppliers based on price would not improve the performance of the regulatory system, however, if wholesale prices continued to be based on embedded accounting costs. Such a distorted pricing system frequently would encourage consumers and distributors to purchase electricity from old high-resource-cost sources instead of from new low-resource-cost sources. $^{135}$ Moreover, mandatory wheeling combined with embed-

${ }^{131}$ See Richard J. Pierce, Jr., Using the Gas Industry As A Guide to Reconstituting the Electricity Industry, - J Res in L \& Econ - (forthcoming 1990) (arguing by analogy from Associated Gas Distributors, 824 F2d at 998-1001, and Maryland People's Counsel $v$ FERC, 761 F2d 768 (DC Cir 1985)).

${ }^{132}$ See Associated Gas Distributors, 824 F2d at 998.

${ }^{133}$ To get a flavor of the difficulty of this interpretive issue, see Farmers Union Central Exchange, Inc. v FERC, 734 F2d 1486 (DC Cir 1984); Consumers Union v Sawhill, 512 F2d 1112 (Temp Emer Ct App 1975); FPC v Texaco, Inc., 417 US 380 (1974). See also John Wyeth Griggs, Competitive Bidding and Independent Power Producers: Is Deregulation Coming to the Electric Utility Industry?, 9 Energy L J 415 (1988); Leonard L. Coburn, Oil Pipeline Regulation: Has the FERC Finally Slain the Minotaur?, 6 Energy L J 209 (1985); Leonard L. Coburn, Farmers Union II: Sisyphus Starts Up the Hill Again, 5 Energy L J 309 (1984).

134 See Pierce, 72 Va L Rev at 1214, 1215 (cited in note 125); Kevin Kelly and J. Stephen Henderson, Some Economic Principles for Pricing Wheeled Power (NRRI, 1987).

13s See Tye, 8 Energy L J at 370-74 (cited in note 125); Pace, 8 Energy L J at 278-79 (cited in note 125). 
ded cost pricing looks suspiciously like a pure transfer of wealth to special interest groups. ${ }^{136}$

The mandatory wheeling example illustrates two significant problems with reading Sunstein's proposal as an instruction to judges to interpret statutes in a manner that will improve the performance of a regulatory system. First, a judge must learn a great deal about the operation of a particular regulatory system before she can implement such a canon with confidence. Most generalist judges are far too busy to take this essential step. Second, such statutory interpretation frequently is contingent on the other policies the agency adopts to implement the regulatory system. This problem of interrelationship could be solved in theory if one judge reviewed all agency policy decisions, many of which reach the courts characterized as issues of statutory interpretation. That single judge could then implement Sunstein's canon by selecting the combination of statutory interpretations that the judge expects to improve the performance of a regulatory system..$^{137}$

This theoretical possibility is inconsistent with the institutional characteristics of the judiciary, however, in at least three ways. First, different judges are likely to be required to address functionally related interpretive issues. ${ }^{138}$ One judge might, for instance, apply Sunstein's "improve the performance of the regulatory system" canon by interpreting FERC's statutes to confer on it authority to require mandatory wheeling, on the assumption that FERC can and will allow wholesale prices to be determined through a process of competitive contracting. Another judge might apply the same canon to yield an interpretation of FERC's statutes that requires it to base wholesale prices on embedded accounting costs, on the assumption that FERC lacks the power (or will not exercise the power) to order mandatory wheeling. Each interpretation might be correct based on each judge's plausible assumptions, but they are obviously incompatible. ${ }^{139}$ The combination would impair significantly the performance of the regulatory system because the interpretations are premised on inconsistent regulatory models.

\footnotetext{
136 Tye, 8 Energy $L J$ at $368-74$ (cited in note 125).

${ }^{237}$ For an example of this approach, albeit in a dissenting opinion, see Mobil Oil Exploration and Producing Southeast, Inc. v FERC, 885 F2d 209, 226 (5th Cir 1989) (Brown dissenting on basis that combination of policies agency implemented made sense once relationship among policies was understood), cert granted, $110 \mathrm{~S} \mathrm{Ct} 2585$ (1990).

${ }^{238}$ Compare Associated Gas Distributors, 824 F2d 981 (affirming cluster of FERC policy initiatives), with Mobil Oil, 885 F2d 209 (reversing cluster of FERC policy issues closely related to those affirmed in Associated Gas Distributors).

${ }^{130}$ See Tye, 8 Energy $L ~ J$ at 337 (cited in note 125); Pace, 8 Energy $L$ J at 265 (cited in note 125).
} 
Second, most judges are too busy to educate themselves to the extent necessary to recognize the critical functional relationship among interpretive disputes. The judiciary as a whole is likely to blunder into one of two incompatible sets of interpretations, that is, mandatory wheeling combined with prices based on embedded accounting costs, or no power to impose mandatory wheeling combined with prices based on competitive contracting.

Third, given judges' limited ability to educate themselves concerning the effects of alternative statutory interpretations, and the contestable nature of the effects we have described, each judge is likely to rely on her own general beliefs as her principal basis for applying Sunstein's canons. A judge who is skeptical of the efficacy of market forces is likely to believe that the regulatory system will perform best if FERC bases wholesale prices on embedded accounting costs and does not have the power to create competition among utilities by mandating wheeling. A judge who is skeptical of the efficacy of government regulation is likely to have the opposite set of beliefs. ${ }^{140}$ If each of these two hypothetical judges resolves one of the two interpretive disputes through application of Sunstein's "improve the performance of the regulatory system" canon, the agency will be saddled with a combination of incompatible regulatory policies.

The likelihood of this result is considerably greater than this simple example suggests. In order to implement any regulatory scheme effectively, an agency must make a dozen or more policy decisions, many through the process of interpreting ambiguous statutory provisions. ${ }^{141}$ In most contexts, there is more than one combination of policies (statutory interpretations) that offers a realistic prospect of effective regulation. Many of the hundreds of

${ }^{140}$ Compare, for instance, the majority and dissenting opinions in Associated Gas Distributors, $824 \mathrm{~F} 2 \mathrm{~d}$ at 1001, 1018, 1028 (majority expresses confidence in market forces); id at 1044 (Mikva dissenting expresses skepticism), and Mobil Oil, 885 F2d at 216, 219-20, 224 (majority reverses initiatives designed to create competitive market); id at 226-28 (Brown dissenting expresses confidence in market forces).

${ }^{141}$ Consider, for instance, the large number of functionally related policy and interpretive issues FERC has resolved and courts have reviewed over the last five years in FERC's efforts to regulate the natural gas industry. See Associated Gas Distributors v FERC, 893 F2d 349 (DC Cir 1989); American Gas Ass'n v FERC, 888 F2d 136 (DC Cir 1989); Mobil Oil, 885 F2d 209; Kaiser-Francis Oil Co. v Producer's Gas Co., 870 F2d 563 (10th Cir 1989); National Steel Corp. v Long, 689 F Supp 729 (W D Mich 1988); Office of Consumers' Counsel v FERC, 826 F2d 1136 (DC Cir 1987); Associated Gas Distributors, 824 F2d 981; Consolidated Edison Co. v FERC, 823 F2d 630 (DC Cir 1987); Wisconsin Gas Co. v FERC, 770 F2d 1144 (DC Cir 1985). 
possible combinations will not work, however, not because any individual interpretation is "wrong," but because the combination of interpretations is based on incompatible policies. With the entire federal judiciary potentially involved in the process of judicial review of agency statutory interpretations, and with those judges' beliefs covering a wide ideological spectrum from extreme skepticism of market forces to extreme skepticism of government intervention, the probability is high that an agency will be handicapped by some combination of incompatible statutory interpretations imposed by well-intentioned judges of differing ideologies. ${ }^{142}$

3. Sunstein's canons as a general instruction to minimize the effects of factionalism.

Like most of the innovative proposals that pour from the pen of this prolific scholar, Sunstein's canons are designed to counteract the tendency of political institutions to reflect majoritarian and minoritarian factionalism. ${ }^{148}$ The enterprise is worthy of serious scholarly attention. Madison's predictions of factionalism in democratic institutions ${ }^{\mathbf{1 4 4}}$ have proven accurate, and the Framers' structural checks have not completely avoided the effects of factionalism in the administrative state. ${ }^{145}$ Some of the many legal doctrines Sunstein proposes in his effort to reduce factionalism offer considerable promise. ${ }^{146}$ His canons do not, however, in part because the phenomenon of factionalism is more complicated than Sunstein assumes.

For courts to counteract factionalism in the administrative state through the process of statutory interpretation, they must be able to identify a form of factionalism that manifests itself on a reasonably consistent basis in implementing a particular regulatory regime. Typically, the statutory interpretation that counteracts mi-

142 Compare Environmental Defense Fund, Inc. $v$ Ruckelshaus, 439 F2d 584, 593-94 (DC Cir 1971) (EPA cannot defer decision to suspend pesticide registration pending further investigation once it becomes aware of serious health hazard), with Love v Thomas, 858 F2d 1347, 1357-63 (9th Cir 1988) (EPA cannot exercise suspension power until it has investigated effects of suspension, even when it knows of serious health hazard). See also Pierce, 64 NYU L Rev at 1252-54 (cited in note 9).

14s See Sunstein, 97 Yale L J at 1539, 1560-61, 1587-89 (cited in note 6). See also Cass R. Sunstein, Naked Preferences and the Constitution, 84 Colum L Rev 1689, 1710-32 (1984)

14 Federalist 10 (Madison) in Cooke, ed, The Federalist at 56 (cited in note 60).

${ }^{245}$ See Sunstein, 103 Harv L Rev at 475-77 (cited in note 1); Sunstein, 97 Yale L J at $1556,1560-61,1587-89$ (cited in note 6).

1*6 See, for example, Strauss and Sunstein, 38 Admin L Rev at 188-94 (cited in note 97). 
noritarian factionalism is the converse of the interpretation that counteracts majoritarian factionalism. In many contexts, however, either form of factionalism can arise, depending on the political environment in which an agency is operating. ${ }^{147}$ That political environment can change dramatically from period to period, suggesting the need for different statutory interpretations in different time periods.

This phenomenon of factional cycling can be illustrated with reference to the regulation of electric utilities. Paul Joskow has shown empirically that electric utility regulation was characterized by minoritarian factionalism during the 1950 s and most of the 1960 s. $^{148}$ The combination of declining costs, a technically intricate regulatory process, information asymmetries, and collective action problems conferred on utilities the power to obtain regulatory results systematically advantageous to them and disadvantageous to consumers.

One of the authors has demonstrated empirically that electric utility regulation has been characterized by majoritarian factionalism during the 1980s. ${ }^{149}$ Increasing costs and easily communicated symbols of utility greed inflamed public passions, activated previously dormant consumer groups, and pressured regulators to behave opportunistically by reallocating billions of dollars of wealth from utilities to consumers.

The potential for factional cycling exists in many other contexts. ${ }^{150}$ This suggests another set of problems for judges called upon to interpret regulatory statutes in a manner calculated to counteract factionalism. Judges will have to adopt different interpretations of the same statutory provisions in different periods of time, depending on whether the political and regulatory environment of the moment is spawning majoritarian factionalism or minoritarian factionalism. This, in turn, suggests the need for judges to engage in careful empirical research concerning the effects of an agency's actions in differing political environments. It does not seem realistic, however, to expect overworked generalist judges to undertake extensive empirical research when reviewing an agency interpretation of a regulatory statute. Indeed, judges lack the time and resources required even to conduct a thorough search of the

\footnotetext{
${ }^{142}$ See Komesar, 86 Mich L Rev at 671-83 (cited in note 33).

148 Paul L. Joskow, Inflation and Environmental Concern: Structural Change in the Process of Public Utility Price Regulation, 17 J L \& Econ 291, 305-11 (1974).

149 Pierce, 77 Georgetown L J at 2048-53 (cited in note 106).

1 so Id at 2075-77.
} 
secondary literature and to read that literature carefully and critically before adopting a particular statutory interpretation designed to counteract factionalism. Given judges' limited ability to identify factional cycles through careful empirical research, they are likely to base statutory interpretations on the propaganda of the thendominant faction, thereby reinforcing the power of that faction. ${ }^{151}$

$$
* * * *
$$

In sum, Sunstein's instructions to judges called upon to interpret agency-administered statutes would read something like this: You should defer to agency interpretations unless you believe that they are the product of a political pathology or will lead to a regulatory pathology. You should interpret statutes in a manner consistent with congressional intent unless you believe that Congress's intent was a product of a political pathology or will yield a regulatory pathology. Whenever you identify a political or regulatory pathology, your responsibility is to interpret the statute to avoid or counteract that pathology even if such an interpretation is inconsistent both with the agency's interpretation and with your determination of congressional intent. You should refer to the vast literature in political science, political economics, and public law to identify political and regulatory pathologies. I have given you a head start in mastering that literature by identifying about twenty pathologies that should guide you as you embark on this herculean adventure.

Giving an instruction of this nature to the 800 mere mortals that constitute the federal judiciary is a prescription for cacophony in the administrative state. Any method of interpretation, whatever else it accomplishes, must be consistent with the institutional characteristics of the interpretive community, the judiciary. Sunstein's bold proposal fails that threshold test.

${ }^{131}$ See, for example, Barasch v Pennsylvania Public Utility Comm., 516 Pa 142, 532 A2d 325 (1987), aff'd as Duquesne Light Co. v Barasch, $109 \mathrm{~S} \mathrm{Ct} 609$ (1989) (interpreting newly enacted ambiguous state statute to require state utility commission to disallow recovery of all investments in canceled power plants). 
$+$ 